Santa Clara University

Scholar Commons

Economics

Leavey School of Business

2003

\title{
Improving Design and Performance of Group Lending: Suggestions from Burkina Faso
}

Michael Kevane

Santa Clara University, mkevane@scu.edu

Barbara MkNelly

Follow this and additional works at: http://scholarcommons.scu.edu/econ

Part of the Economics Commons

\section{Recommended Citation}

Kevane, Michael and MkNelly, Barbara, Improving Design and Performance of Group Lending: Suggestions from Burkina Faso. World Development, Vol. 30, No. 11, 2003. Available at SSRN: http://ssrn.com/abstract=1096253 
Draft: Comments welcome

April 19, 2002

\title{
Improving Design and Performance of Group Lending: Suggestions from Burkina Faso
}

\author{
Michael Kevane \\ Department of Economics \\ Santa Clara University \\ Santa Clara, CA 95053 \\ mkevane@scu.edu \\ 408-554-6888 \\ 408-554-2331 fax \\ Barbara MkNelly \\ Freedom from Hunger \\ 1644 Da Vinci Court \\ Davis, CA 95616 \\ bmknelly@freefromhunger.org \\ 530-758-6200 \\ 530-758-6241 fax
}

Keywords: microfinance, group-based lending, gender credit, Africa, Burkina Faso

\begin{abstract}
We summarize lessons learned by a credit program for women in Burkina Faso. Three observations are made regarding program design: 1) high membership turnover means mutual guarantee groups should be smaller and more central to non-repayment penalties; 2) high turnover in economic activities implies more training in best practices and more variety and experimentation in credit and savings mechanisms; and 3) high degrees of stocking activity suggests the need to develop instruments to mitigate commodity price risk at the individual and program level. Three observations are made regarding program implementation: 1) be more consistent in the treatment of debts of deceased borrowers; 2 ) become more sensitive to the complexity and variety of procedures followed in the event of non-repayment; and 3) devote more attention to preventing and mitigating the effects of staff embezzlement.
\end{abstract}




\section{Introduction}

The microcredit boom is finally reaching West Africa. In the past, only pockets of privileged cash-crop producers had access to formal financing. Women were typically excluded from formal finance regardless of their activities. In the last decade, a myriad of microcredit schemes have changed this situation by targeting rural women and petty traders. ${ }^{1}$ Table 1 lists the major finance institutions that report statistics to the secretariat of the Microcredit Summit, including the Fédération des Caisses Populaires du Burkina Faso, which is the focus of this paper. As of mid-2001, about 40 institutions served approximately 650,000 clients. Table 2 reproduces data from Fruman and Paxton (1998) to give an idea of the rapid growth of four West African microcredit institutions during the 1990s in terms of loans and clients.

The newness of microcredit in West Africa means there are potentially large rewards from careful attention to issues of program design and implementation. Lessons learned from Asian and Latin American experiences may not be applicable to West Africa. Population densities in West Africa are low, and much of the population is not literate. There is little road and communication infrastructure outside of capital cities. The economy remains agrarian, dependent on the vagaries of the weather. All of these conditions pose formidable challenges to the sustainability and targeting goals of microcredit institutions.

We use the experience of a microcredit program in Burkina Faso to draw attention to certain aspects of performance, design, and implementation of microcredit projects. We hope to extract useful lessons for other credit institutions, particularly those in West Africa, that use group-lending methodologies. The research is based on two visits to the same program communities by one of the authors, first in November 1996 and then in February 2000. Since the program had been operating in these communities for two to three years when the initial visit was made, this approach allowed for community and program dynamics to reveal themselves over a relatively long five- to six-year implementation period.

\section{Credit with Education in Burkina Faso}


The case study that is at the heart of the paper of a program called Credit with Education, which combines elements of the Grameen Bank and village banking methodologies. The program began in 1993 and exclusively serves women. Women are believed to be lacking in collateral for ordinary loans and ignored by formal financial institutions (Pal 1995). The targeted program communities are very poor, usually lacking electricity and access to healthcare services. Very few of the clients have had any previous experience with formal financial institutions. This is changing, as the microfinance field becomes more crowded, and a government-sponsored program has expanded throughout the country.

The program encourages women to group themselves into solidarity groups that will have joint liability for borrowed loans. Several solidarity groups are then organized into a Credit Association for a twotier system of mutual guarantee. The theory is that small solidarity groups will boost repayment rates. There are a number of mechanisms through which this might happen (Ghatak and Guinnane 1999). There is an enforcement mechanism, as members of small borrower groups can use social sanctions against defaulters. Likewise, the small groups can monitor behavior among themselves and take quick action to forestall default. The incentive effect of linking the provision of future loans for each and every member to the complete repayment of the group loan is a powerful motivator to encourage and enforce repayment. There is also a screening function. Presumably, members will not form groups with risky borrowers. Finally, group members might insure each other, thus reducing the variance of loan outcomes. The joint-liability has been a major methodological breakthrough for lending to the very poor. It substitutes for physical collateral and the need for the lending institution to undertake costly assessments of an individual's creditworthiness. Bundling many small individual loans into a group-based point of service, together with mutual guarantee mechanisms, has made lending to the very poor financially viable and even profitable for some organizations.

As mentioned, the Credit with Education program is a hybrid of group-lending approach and village banking. Although Grameen Bank replicates and village banking interventions have evolved over time and 
moved closer to each other in their lending terms and policies, several important distinctions can still be made between these two approaches. Grameen-type programs typically: 1) screen clients on the basis of socioeconomic characteristics to preferentially target the poor, 2) organize members first in solidarity groups (four to seven persons) and then combine several solidarity groups to form a larger Center, 3) disburse staggered loans with one or two solidarity group members demonstrating their repayment performance before others receive their loans, and 4) have officers elected from among the members and entrust them with a major, almost profesional, role in Center management and recordkeeping.

Village banking programs typically do not use official screening mechanisms. Joint-liability extends across the entire group of approximately 20 to 40 persons. Individual loans are disbursed, and fall due, on the same day with all members adhering to the same "loan cycle." From the perspective of the lending organization, the village bank is jointly responsible for a single loan that must be fully repaid before another loan is made. Recordkeeping of individual borrowing, repayment and savings transactions is maintained only at the village bank level. Fostering the self-management capacity of the village bank is emphasized. The original model assumed that after a short time members' own savings would replace program capital and the village bank would operate autonomously.

Credit with Education, like the Grameen methodology, has group formation occuring first through self-selected solidarity groups which are then organized into a larger Credit Association. But like other village banking programs, clients are not screened for poverty characteristics, members of a village bank adhere to a common loan cycle which is tracked by the institution as a single loan and joint-liability is applied across the entire village bank.

Credit with Education is managed by a credit union network in Burkina Faso, the Fédération des Caisses Populaires du Burkina Faso (FCPB). ${ }^{2}$ Credit unions have some of the key prerequisites to succeed in implementing microcredit programs (Larivière and Martin 2000; McDonald 2000; Oberdorf 1999). They have 
an existing financial structure, outreach capability, and considerable liquidity in need of diversification. They also share the goal of equitable development that inspires many microcredit programs. The FCPB in particular is a federation of 65 credit unions or caisse populaires with about 150,000 members, modeled on the Canadian Desjardins movement. Much of the FCPB's growth and liquidity has been fueled by urban members who outnumber rural members three to one (Frankel and others 1999). Despite the high prevalence of urban members, more of the credit union branches are actually located in rural rather than urban areas so the FCPB has an infrastructure with considerable rural outreach.

The program has four objectives: 1) raise the incomes that women earn directly through their own market activities; 2) promote savings; 3) reinforce and deepen the bonds of collective solidarity among women, enabling them to participate more directly in village and regional institutions; and 4) improve local knowledge regarding health and nutrition practices and business management. The program uses the naturally interactive forum of regular group meetings for focused and participatory learning sessions on health, nutrition and business development. While committed to financial self-sufficiency, the integration of the education component reflects a conscious judgement that microcredit is not enough. To overcome chronic hunger and malnutrition, rising incomes must be coupled with participatory, non-formal education about child survival, family planning, women's health, and business development topics.

The program works in the following way. One or two loan officers (known as animatrices, or “animators") are assigned to a credit union to promote Credit with Education in surrounding communities that are as far as 35 kilometers from the credit union. Rather than have individual women travel to the credit union, the animatrice and the credit union's loan, using a motorbike, go to the women. Women join Credit Associations with an average of 25-35 members, with smaller "solidarity" groups of five to seven members. Each Credit Association sets up an account at the local credit union and borrows as a group. The Credit Association counts as a single credit union member and the association as a whole is legally liable for the 
entire loan. The loan size equals the sum of the individual loan amounts, which vary from 5,000 to 300,000 CFA (approximately US\$8-\$520). Loans are given in cycles varying from short, four-month cycles for new associations to longer, six-month cycles for mature associations. Repayments are initially made weekly, but after several loan cycles are extended to monthly. Borrowers, of course, frequently complain about the frequent repayment installments, but practitioners consider them essential to sustaining high rates of repayment.

The borrowers pay a flat rate of 10 percent interest to the credit union per loan cycle (this amounts to an effective rate of 20 to 30 percent APR, since a flat rate is charged on a declining balance). The penalty for non-repayment by the Credit Association is exclusion from future loans. As noted above, the innovation of group lending was to draw on group screening; social solidarity, peer pressure and local monitoring minimize the likelihood of default (Edgcomb and Barton 1998; Nelson and others 1996). In theory, the Credit with Education program had a kind of two-tier joint-liability structure. In the event of repayment problems, a borrower's small solidarity group was expected to cover the loan installment. If the solidarity group proved unable to repay, liability fell on the entire Credit Association membership. While there were differences across Credit Associations, solidarity groups in practice seemed not to be very operational and repayment problems tended to be resolved by the larger Credit Association. The Credit Association as a whole would be excluded from further loans in the event of default.

Members also are required to save, during the loan cycle, a relatively small mandatory amount (approximately five percent of the average loan). Voluntary savings above this amount are also encouraged and can also be accessed at the end of the cycle. In addition, borrowers pay into a group fund, to be used for association activities or projects. During the regular repayment meetings, the animatrice leads a prepared participatory learning session on business or health education. The associations manage the savings funds and group funds, implement association-sponsored projects and host the educational sessions. 
The Credit with Education program has expanded rapidly throughout Burkina Faso, as seen in Table 3. By the end of 2000 , the program had over 27,000 borrowers and approximately 33,000 members (some women choose not to borrow but are still considered active members if they maintain savings and participate in the Credit Association regular meetings and education sessions). The program has loaned out almost five billion CFA, or about US\$10 million at an average exchange rate of 500 CFA per dollar.

The surest measure of program success is that the FCPB has continued to implement and expand Credit with Education services years after the end of the technical assistance and financial cooperation with Freedom from Hunger. In 1997, the FCPB officially institutionalized Credit with Education as part of the regular financial products offered by credit unions. The great majority of FCPB credit unions have added Credit with Education to its array of financial services and products. Each of these credit unions manages an average of 25 Credit Associations (Frankel and others 1999). Across the network, about 100 animatrices work directly with the Credit with Education Credit Associations.

Initially attracted by its social goals, the FCPB has demonstrated that there are a number of good business reasons for offering a poverty-focused loan product (Stack and Thys 2000). The FCPB could penetrate new markets to enlarge its membership. The new program diversified the portfolio of the FCPB, since loans to women were typically invested in fast turnaround commercial activities as opposed to longerterm fixed investments. The regular weekly or monthly repayments spread out cash flow, which might otherwise be strongly seasonal. Finally, the new, female clients of the program had much higher repayment rates than the traditional, male clients.

\section{Design and Implementation Issues}

Notwithstanding the overall success of the program, a close look at implementation on the ground reveals strains and flaws in the system. The flaws are significant because of the importance of mutual trust and 
shared expectations in credit institutions. Credit institutions are vulnerable to runs or self-fulfilling

prophecies: a small incident may quickly escalate to large-scale defaults as borrowers adopt pessimistic expectations about the survival of the institution and its ability to enforce repayment and continue extending credit (Paxton, Graham, and Thraen 2000).

This section discusses six observations that pertain to design and implementation issues. The discussion uses qualitative studies from three villages in Burkina Faso. The first village, Tingandogo, is located just south of the capital, Ouagadougou, and women in the village spend considerable time processing local food stuffs such as sorghum and soumbala (a spice processed from fruit of the nere tree) for sale in the big markets of the city. The second, Nagreongo, is a rapidly developing village along the major east-west road linking Burkina Faso to Niger. The village has benefited from proximity to a prominent traditional healer and an onion irrigation project. The third, Ipendo, is a more isolated, large and dispersed village (though also on a major road) with a small but bustling market that draws from even smaller surrounding villages. There were two separate associations in Ipendo, later merged into one. Residents were quick to point out the lack of economic opportunities in the village.

Borrowers in the three villages were interviewed in November 1996 and again in February 2000. Virtually all borrowers currently in the program were interviewed, as well as some borrowers who had left the program. In addition, interviews were conducted with key informants in villages (schoolteachers, chiefs) and with staff in the field and in Ouagadougou.

\section{a. Design Issues}

(i) Program design should recognize the possibility of sizable fluctuations in membership and make mutual guarantee groups smaller and solidarity groups more central to non-repayment penalties.

Membership turnover has been relatively high in the credit program, and this has direct implications for the group-lending model. Although on average the per annum drop-out rate has been relatively modest (6 
to 12 percent), there have been periods of more pronounced membership change and/or contraction. In the four associations in the three villages, numbers of borrowers started small, rose quickly, approaching almost 60 members in two of the associations, then fell dramatically, as seen in Chart 1. After several years, the borrowers in the program were not usually the same ones who had started. In Nagreongo, borrowers and loan amounts were fairly stable until 1999 , when in the 11th loan cycle a series of late repayments by a neighboring Credit Association led to delays in processing of new loans (details below). In the welldeveloped market village of Tingandogo, a full 67 percent of early borrowers were still in the program after four years. But subsequent turmoil led to considerable drop-out from the program. A group of borrowers left during the seventh and eighth cycles to join women from a neighboring village in a new Credit Association. That association experienced repayment difficulties, and by the ninth cycle ten women were incorporated back into the original Tingandogo association. Some were old members, and some were from the failed association. In the more remote village of Ipendo, the associations saw a steady decline following the peak participation in the eighth cycle. In early 2000, membership in the two associations of the village had dropped from a total of over 160 to barely 30, and the two associations were merged.

Chart 2 gives an indication of how the nature of the program also changed, in terms of credit transacted. Loan sizes soared for borrowers in the onion-growing village of Nagreongo, reaching an average of more than 200,000 CFA (approximately US $\$ 320$ or roughly equivalent to the average per capita annual income in Burkina Faso). Average loan size also rose rapidly in the market village of Tingandogo as did the variability in loan size across borrowers. While many women borrowed up to the maximum loan, many others preferred to continue with small loans. In the remote and relatively commercially undeveloped village of Ipendo, for example, many women discovered over time that working capital was not the primary constraint in sales expansion for loan activities such as producing dolo (local sorghum beer) and beurre de karité (a 
cooking oil/condiment) and food processing. Loan sizes remained small, with only a few women borrowing large amounts.

In general, associations experienced high turnover and increasingly varied borrowing behavior. This poses a problem for group lending, with its commitment to joint liability and mutual guarantee. Large, relatively anonymous, and high-turnover associations that have considerable variety in borrowing patterns probably do not benefit much from the potential strengths of a joint-liability mechanism. The problem stems from the absence of the real self-selection essential for joint liability to function (Edgcomb and Barton 1998). If membership of the group or Credit Association is constantly changing and smaller groups are merged with existing ones for administrative efficiency, the self-selection and enforcement functions of the joint-guarantee mechanism lose effectiveness. Longer-term members are less familiar with the repayment capacity of new members. New members will be jointly guaranteeing the larger loans typically taken by longer-term borrowers. Moreover, a large group with lots of turnover may not be able to overcome the free-rider problem of making up the loans of defaulters. Each member has an interest in contributing some amount, if other group members also contribute, so that all can get new loans. But each member also has an incentive to let other, wealthier, members pick up a bigger share of the burden. So while large, heterogeneous groups may have a greater potential capacity to cover repayment problems, they could face more lengthy delays in "negotiating" the response to defaults. Paxton (1996) noted a similar phenomenon in a different group-based credit program in Burkina Faso. She suggests that in good years the mutual guarantee mechanism common to group lending may result in higher repayment than individual lending but poorer repayment in bad years due to this domino effect.

The joint-guarantee mechanism across the entire Credit Association rather than the smaller solidarity groups leads to greater inconvenience and dissatisfaction for "good" borrowers. The failure of only one member to repay will prevent the members of the entire Credit Association from receiving a new loan. 
Although this certainly broadens the social peer pressure to repay, depending on the size of the Credit Association, it means that as many as $20-50$ "good" borrowers are denied access to new loans. Since this is the primary motivator for good repayment performance, this inconvenience could likely become a disincentive to repay or at least to continue with the program.

Note that suspension of large groups, in the event of non-repayment, has two negative consequences for the FCPB. First, new loans will not be issued to a large number of people, even though the animatrice is typically still required to visit the site regularly in an effort to collect on the old loan, so costs remain while revenues decline dramatically. Second, in the event of likely non-repayment, members who intend to repay could nevertheless delay or withhold payment of the final loan installment as the group negotiates how to make up for the few defaulters. The FCPB then loses interest earnings on a large amount of the final installment.

The question that arises is the optimal size of a mutual guarantee group. Unfortunately, the economic theory of group lending has little to say on this question. Neither has careful empirical work been done on the group sizes that emerge spontaneously from informal rotating savings and loan associations. These informal groups are known as tontines. Pal (1995) found many of the Credit with Education members had previously participated in tontines. The lack of reasonable criteria for group size should not be an excuse for having a "one size fits all" policy, but rather an invitation to experimentation with different group sizes. Smaller groups in the same geographic area may be required to meet simultaneously. This maintains the efficiency of having credit officers visit only a few sites, while mutual guarantees would extend only across the smaller solidarity group. 
(ii) Program design should recognize high turnover in economic activities and offer more training in best practices and more variety and experimentation in credit mechanisms.

Women in all three villages have experienced considerable change in the activities they pursue. During the first years of the program, women were making significant investments in their productive capacity (buying larger cooking pots, buying clay jars for storage, improving market stalls, doubling working inputs, etc.). It appears that these initial investments were the one-time result of relaxing the capital constraint on women. By 1999, very few women seemed to be making large investments in productive capacity. Instead, many successful women were switching to activities that required higher working capital but not higher fixed investment. They were becoming traders and retailers rather than producers. In Tingandogo, one woman, who had formerly taken vegetables from irrigated market gardens to sell in the capital, Ouagadougou, had now moved to Ouagadougou and was trading in reverse, taking cloth from the central markets and selling it in village markets. Another woman who previously made soumbala was now operating an open-air food stall for the workers at the dam, selling 'fast-food' rice prepared with sauce.

High turnover in activities offers a window of opportunity to a program such as Credit with Education that explicitly links credit with nonformal education. As women move up the ladder of economic activities, they often engage in costly learning by doing. More resources could be devoted to delivering information sessions to reduce some of those costs and enable women to learn from one anothers' experiences. The newer Credit with Education programs are incorporating learning sessions about business development topics (increasing sales, money management, credit-use strategies, etc.) to foster this type of learning.

High-activity turnover has another implication for program implementation. Group-lending implementers typically consider standardization essential to cost-effective operations. Program operations and record-keeping can be highly decentralized when credit terms are simple and standardized (Oberdorf 1999). 
Over time, however, client needs are likely to evolve and demands become more varied within groups.

Paxton (1996) refers to this as a matching problem. For the first loans, group members have self-selected to access the particular kind of loan that is offered. After a few loan cycles, however, group members begin to build up their own capital. The standardized loan package, with fixed dates for loans disbursement and repayment, becomes less attractive for many. The FCPB is flexible in that all borrowers need not take the same loan amount and women who do not want a loan at all are allowed to remain members. The program is not, however, flexible in modifying the disbursement times and repayment schedules. Inflexible loan terms are one of the major reasons for client exit from the program.

A stark example of the mismatch between standardized lending terms and economic opportunities occurred in Nagreongo. Another NGO, the Hunger Project, had subsidized the renovation of a small irrigated area for dry season onion-growing. Each woman in the village received land enough to produce on average 16 sacks of onions. Since the onions were selling for about 25,000 CFA per sack, and the expenses for inputs purchased through a cooperative group subsidized by the Hunger Project were only about 20,000 CFA, onion farming was very profitable. But it was clear to all the women that monthly repayments required by the Credit with Education were not conducive to this activity. The return on the investment only occurred after four or five months, or even longer if the onions were to be stored for several months until after the harvest season when prices were higher. There was a strong demand by some women for six- or eight-month loans, with repayments at the end of the loan period after harvest and marketing of the onions. The general point is that as the local economy changes in response to the provision of new infrastructure and new institutions, the lending program should be able to adapt accordingly. However, it should also be acknowledged that most microfinance programs, even those operating in rural areas, consider agricultural lending inherently more risky and resist tailoring their lending terms to the type of investment profiled in this example. Unfortunately, the normal policy of the FCPB to "graduate" women into individual loans cannot be successful in rural areas 
where women have little formal title to assets that might be used as collateral and are considered legal minors under the authority of their husbands.

A major challenge for highly decentralized group-lending programs such as the FCPB is how to offer more flexible financial services which promote client retention by better meeting clients' needs while keeping costs down. Part of the answer may lie in experimenting with more varied repayment schedules and loan lengths. The trick of course is to sustain mutual guarantees when the terms for individual loans are different; the issue of solidarity-group size is again crucial (Brand 2000). Extensive recent literature has also underscored the value of savings services to the poor (Rutherford 1999; Wright 2000). While the FCPB has made some real improvements to savings services, such as reducing compulsory amounts and allowing access at the end of loan cycles, this component of the strategy could be enhanced. For example, practices such as seizing clients' savings to cover other members' late loan repayments is effective in the short-term but undermines members' long-term trust in the savings services.

\section{(iii) Program design should recognize high degree of stocking activity and develop instruments to mitigate commodity price risk at the individual and program level.}

Women in all three villages devoted sizable fractions of their loans to stocking agricultural commodities, either for use in later production or to realize profits from price increases. These commodities include groundnuts, sorghum, and rice. One woman in Nagreongo, for example, had taken her latest loan of 50,000 CFA and invested one-half into buying five sacks of groundnuts. The remainder she had set aside for her repayments until she would sell the groundnuts. Another bought four sacks of rice for 20,000 CFA.

There were obvious risks in this strategy, risks not apparent until 1999-2000, when for the first time in recent memory grain and groundnut prices started falling after the harvest rather than rising. So women who had bought commodities immediately after the harvest found themselves holding stocks worth less; difficulties in 
repayment were consequently compounded. Stocking exposes women to commodity price risk, and, more importantly, exposes the program to a macro risk that is difficult to insure spatially, but rather needs to be insured inter-temporally.

In light of recent interest in providing insurance components to microcredit schemes, some effort might be devoted to considering a small-scale market for insurance against price risk. We might imagine, for example, that the FCPB offers a service, open only to members, of selling "futures" contracts for grain and groundnuts. These contracts would come in specified amounts and schedules of repayments based on standard prices published in official government bulletins. For example, a 500 CFA contract might pay nothing if the price of groundnuts is higher than the target price, but return 10 CFA for every CFA below the target price. Obviously price setting for these contracts would have to be determined on the basis of historical changes in post-harvest prices, but there is nothing in principle to prevent the FCPB from acquiring the expertise to price these contracts with positive expected profit. Rural residents in Burkina Faso and elsewhere in the Sahel are averse to risk, so the possibility of mutually advantageous risk-sharing is clearly present.

\section{b. Implementation Issues}

\section{(i) Program implementation must be more consistent in the treatment of}

\section{debts of deceased borrowers}

In all three villages, group loans had been seriously disrupted due to controversy over how to deal with repayment of loans taken by borrowers who then died. In two cases, the families of the deceased had publicly agreed to repay the loans, but then had not actually repaid at the time the loan was due. In two other cases, both in Ipendo, the families repaid only after lengthy interludes. In one case, the husband of the deceased woman left for Côte d'Ivoire and eventually returned and repaid the loan; in the other case, the son 
of the deceased woman repaid her loan. While the associations struggled with the problem over how to deal with repayment, disbursements of loans to the associations were delayed.

Interviews with animatrices and staff members suggested that the FCPB had not effectively promulgated clear guidelines on this issue. One senior staff member declared that the official policy of the program was that the group was responsible for repayment if the deceased's family did not repay. The staff member added, however, that the program would not actually make the group repay. If the group wanted to repay the member's loan, that was fine, and if the group failed to pay it could continue to receive loans. Other staff suggested that on the contrary, if the group failed to make the repayment, the credit union that had extended the loan would simply take the funds out of the group fund belonging to the Credit Association.

Respondents offered different accounts of the level of family responsibility for repaying the loan. Many cited local custom, where at the funeral a request would be made for all those who had unsettled loans to step forward and publicly declare the amounts, that the family might settle accounts. (The dominant ethnic group of the region is known as the Mossi group.) Others noted that the typical deceased woman had few assets, and her working capital may have been spent on medicines or consumption during her illness while she was unable to work. The family might then declare that they did not have the resources to repay, and there was no authority that could compel them to repay. The problematic nature of this issue becomes apparent when a woman of a family with the means to repay dies, but the family refuses to repay. More often, a member dies and leaves her family to cope with the economic distress that follows. Attempts to collect on program debt exacerbate this hardship.

There is a simple solution to this problem, one followed by the individual loan product of the FCPB, which is to add a small charge per loan to a central fund that covers repayments in the event of death. Since mortality rates can be roughly approximated (even in an information-poor society such as Burkina Faso), the rate can be set to just cover the expected repayments. There seems to be no reason preventing the group- 
lending scheme from implementing such a small program change as loan insurance or at least develop a consistent program-wide policy in the event of a borrower's death.

(ii) Program implementation must become more sensitive to the complexity and variety of procedures followed in the event of non-repayment

Raising the delicate issue of how to handle loan repayment in the case of death is not just being a program busybody. It is precisely this kind of detail that successful organizations resolve in a systematic, bureaucratic manner. In many group-lending program and training manuals, non-repayment is a simple matter. A defaulter belongs to a solidarity group that is responsible for full repayment. If a borrower does not fully repay, then everyone in the solidarity group is denied future loans. With the Credit with Education approach, the entire Credit Association is ultimately held liable for the debt; the animatrice will not issue a new loan to the group until the total amount of principal and interest is paid. Loan collection will be handled by the Credit Association and in particular the elected management committee of the association (Nelson and others 1996). The Credit with Education approach turns out to be a hybrid of group lending and village banking methods, where authority to collect loans is devolved to the local management committee. The idea is that the management committee of the local association handles the functions of collecting loans and enforcing repayment, freeing the animatrice to concentrate on promoting new Credit Associations, more general supervision and education.

Actual practice, in the three villages, may be represented as follows (this is an amalgamation of practices recounted by women in the three villages, and not all practices were seen in all three villages). First, the animatrice appeals to the solidarity group and Credit Association to make up the debt. Second, the animatrice and the director of the local credit union withdraw the debt from the Credit Association's accumulated group fund account. Third, the animatrice may then alone, or together with the association 
management committee, threaten the recalcitrant borrower with penalties such as expulsion, a trip to the police station, or confiscation of personal belongings. Fourth, the animatrice uses her connections to local authorities to scare the debtor by having her officially called to the police station. Fifth, the animatrice (perhaps together with some association members) takes some action against the debtor (impounding bicycles, for instance).

Three features of actual practice clearly emerge. First, there was considerable confusion over what, exactly, was meant by group liability. In each village, the consensus was that the entire group was liable for the loan, and hence required to make up any non-repayment The small solidarity groups played no real role, and were not really jointly liable. Most animatrices also ascribed responsibility to the level of the Credit Association rather than solidarity group. .(Schreiner (1999, p. 7) made a similar observation for the Grameen Bank program.) Group liability could be even more complicated. In one village, the animatrice and villagers became embroiled in a debate over whether one Credit Association was liable for a neighboring Credit Association.

Second, the animatrice played a very active role in managing non-repayment. This was not the ideal of the village banking methodology which explicitly aims to foster the self-management of the borrower groups. In principle, there is nothing necessarily wrong with this important role of the animatrice. Indeed one might speculate that the real source of success of group lending is not the peer pressure and reciprocal monitoring, or social collateral, but rather the usual associated intense monitoring by a field agent or animatrice, in contrast to the formerly common "once-per-year visit" by a credit cooperative officer. As we shall see below, however, the practice of high animatrice involvement exacerbates the problem of embezzlement.

Third, note that in the description of actual practice, there was no discussion of final resolution of the default. In practice, this has not been worked out. What if, as is sometimes the case, the defaulting 
borrower or solidarity group eventually comes forward with the money? Sometimes groups have bylaws on penalties for non-repayment, but in all three villages these penalties have consisted of modest fines, rather than continuation of interest charges. According to field staff, the defaulting borrower does not have to pay interest charges on loans with late repayments. So a defaulting borrower may be interested in returning at some point and repaying the old loan, especially if inflation substantially erodes the real value of repayment. If the solidarity group has repaid, then it of course might charge the returning borrower interest on the amount it repaid for the borrower. Across the spectrum, there has been too little interest in designing mechanisms that deal realistically with the incentives and strategies facing individual borrowers having repayment difficulties. High repayment rates are not just an automatic result of mutual guarantee; they also very much depend on client incentives, the existence and clarity of policies, contingency plans, transparency of operations and good management (Edgcomb and Barton 1998).

Interesting differences have been noted about how the peer guarantee mechanism functions in grouplending programs around the world. Montgomery (1996), in a study of BRAC in Bangladesh, reported that when individual group members faced repayment problems they turned to relatives or close friends rather than other members of their borrower group for help in repaying. In Bolivia, among Banco Sol solidarity groups, Mosley [, 1996] found that there was a much higher likelihood that when a borrower had trouble repaying, other group members would be asked to help when the socioeconomic profile of the group was more heterogeneous. He believed better-off members were well aware of the need to help poorer members in the short-term and this assistance often took the form of loans. In cases of default, Montgomery (1996) described how collective action was taken, including forced acquisition of household utensils, small livestock and other assets and even in some cases by violent action such as pulling down a member's house because she had not repaid her housing loan. Conversely, in Burkina Faso, Paxton (1996) found borrower groups were more willing to exert ex ante pressure to encourage complete and timely repayment than ex post 
pressure once default had already occurred. Social sanctions such as negative comments, social exclusion or forced sale of household items were uncommon since the reasons for default (illness or unexpected family expense) were of an uncontrollable nature that borrowers considered legitimate. Even when cases were considered controllable, village harmony was valued more than follow-up so little ex post pressure was applied.

Paxton (1996), for example, finds that groups that have developed specific contingency plans to deal with the inevitable repayment problems due to sickness, travel, and other reasons perform much better than those that failed to plan. Wydick (1999) finds that this internal group organization is also important in determining group repayment.

\section{(iii) Much more serious attention must be devoted to preventing and mitigating the effects of staff embezzlement}

In many villages of Burkina Faso, literacy for women is extremely low. A survey of Credit with Education clients randomly sampled from 23 different Credit Associations had on average less than one year of formal education and only 11 percent were literate. As described above, a distinctive feature of the village banking methodology is the emphasis on building village organizations that are self-managed by the poor. In theory, borrower groups are expected and trained to be self-managed and maintain their own registries and account books. However, the lack of literate members in Burkina Faso seriously undermines this goal. In most villages, the only women who can read the account books kept by the animatrice are younger women who are less likely to be officers of the local Credit Association. They lack authority, in an official sense and also in village hierarchy, even among women. They also are more likely to be in their child-rearing years and have active husbands controlling their work days. In the first years of operation, program representatives encouraged Credit Associations to engage the help of a literate non-member-typically a young man — to help 
with the account registers. This "solution" resulted in many cases of malfeasance and was ultimately dropped. For these reasons, Credit Association members find it almost impossible to maintain the account books. Instead, the animatrice often takes on this responsibility.

The difficulties raised here were evident in two of the three villages. In Ipendo, since the inception of the program, women had wanted to use their group funds to assist in the building of a village dispensary. The group funds, it should be recalled, belong to the group, and come from extra contributions and fines. After several years of negotiating and tax collection, the male village authorities succeeded in raising the funds to complete the bulk of the project. The women approached the animatrice to withdraw funds so that each Credit Association could purchase fifty sacks of cement. They believed they had more than sufficient funds in their group account for the purchase (a sack of cement cost approximately 4500 CFA, so the hundred sacks for the two groups would be 450,000 CFA, or approximately US\$700). Unfortunately, things were not as they seemed.

The animatrice, according to credit association members, had arbitrarily refused to give them the funds requested, and told them they could only buy twenty sacks of cement instead of fifty. Moreover, the animatrice said that they could not withdraw more money to pay for the transport of the sacks, so the village delegate had to pay for the transport. These events, which took place in late 1999, greatly disillusioned the women of the Credit Associations. The unfinished house for the clinician, situated next to the brand-new and completed dispensary, was a daily reminder of their inability to succeed in their dream. It was the major reason women gave for withdrawing from the credit program (and a great many had withdrawn).

Association members did not understand the actions of the animatrice. A careful review of the account books in the summer of 2000 suggested that the women in the village were justified in their puzzlement. Each group account should have had a balance of roughly 500,000 CFA. This review, conducted by one of the authors, was difficult. A full day was spent trying to reconstruct the group funds 
from the account book. The immediate problem in such an accounting was that the account book had no entry for the group fund. There was no carryover from one cycle to the next, and no entries in the log of deposits and withdrawals. Instead, one needed to look at each repayment cycle and add up all payments made into the group funds as part of each individual's repayment. The amounts were large in the beginning of the program because the policy then was to have women contribute 10 percent of their loan as a payment into the group fund.

Therein lay the problem. When the animatrice arrived late in the day in Ipendo and was asked to explain why, if the group funds amounted to 500,000 CFA, she had limited the purchases of cement to only 200,000 CFA, she had a ready answer. After the seventh cycle of loans, the FCPB had changed the policy for the group funds. Realizing (correctly) that 10 percent was much too high, they had decided to limit payments into group funds to the same amount per person (regardless of loan size) and to reimburse the funds previously collected. There was, unfortunately, no record in the account book of that reimbursement. Instead, the animatrice had written on a separate, detached, piece of scratch paper the names of the group members and the amount they were due for reimbursements. This piece of paper had no date or explanation, nor were there any receipts or thumbprints from the women indicating they had received the reimbursement (which for some women totaled tens of thousands of CFA). Finally, the animatrice explained that another new rule had been instituted by the FCPB: all Credit Associations were required to maintain a balance in their accounts of at least 100,000 CFA before taking a new loan, and each individual borrower was required to maintain individual savings of 3,000 CFA from one loan cycle to the next. So the groups simply did not have enough excess funds to be able to buy more than 20 sacks of cement. The accounts were in order, but the only way to verify that was to sit down in person with the animatrice and have her explain all of the accounting irregularities. If she were no longer serving in the area, it would have been impossible to verify the state of the accounts. 
A similar story, without such a reasonable explanation, was told in Nagreongo. It illustrates many of these implementation issues simultaneously. At about the $11^{\text {th }}$ cycle, a number of women from a neighboring Credit Association, Delwende, failed to repay. Meanwhile, in the main Credit Association of Nagreongo, Zoeyande, discontent had arisen over fears that the animatrice had been collecting too much as repayment for the loans and was not giving women individual receipts, nor was she returning their savings to the women. The animatrice declared one day that she would give no more loans to Zoeyande until the women of Delwende repaid. Furthermore, she declared that she would take action against the women of Delwende if they did not repay. True to her word, the animatrice returned accompanied by two police officers from the station of the district capital Ziniaré. The police officers forced a number of women to accompany them to the commisariat in Ziniaré, where they were detained in the courtyard, some for as long as three weeks. Here is how one woman described the events:

I had too many problems with Juliette (a pseudonym for the animatrice), especially regarding the last loan of 100,000 that I had to repay. In my first installment, I gave her 30,000. Then my husband got a letter of convocation from Ziniaré even though the name was for another woman who had the same first name as me but a different last name. So he had to travel all the way to Ziniare just to clear that up. They kept him there for three days in the police station, with Juliette's complicity, and to get him free we had to give Juliette 10,000 as a second installment. Ten days later my husband's mother died of shame. The day of her funeral, I myself received a letter of convocation from the police of Ziniaré. I did not go, and then Juliette came to Nagreongo and in a meeting told all of us that we had 14 days to repay our debts. After 12 days, she came with three police officers from Ziniaré and arrested everyone who owed money. She had them arrest Assetou that day, which was the day of the baptism of her infant, and her husband was not even there, even though she did not owe money-it was her co-wife. That is what happened in my house where my co-wife was arrested instead of me. They took her away from her one-year-old baby. So then I went to Ziniaré and took her place. I was there for 19 days. My husband came and deposited 25,000 and then 20,000 and then 15,000 and then another 20,000 for a total of 120,000. But even then they did not let me go, and I knew my whole amount had been paid. So then I demanded to see the commisaire, and I told him everything that had happened to us in front of all the other women. And then one of the police officers stood up and said that Juliette had promised him 10 percent of the payments if they could make the women repay, and 15 percent extra for any payments above the payments we were supposed to make... that is, 25 percent of any extra payments. At that point the commisaire got mad and he had everyone freed and said he would do his best to have this issue resolved peacefully even though Juliette wanted him to arrest people and put them in prison. Then several months later Juliette came again and we gave her another 16,875 CFA. Juliette has never come back to Nagreongo since that day. The women of the village 
who did not take credit are now mocking those of us who did and had problems with the police. It is very humiliating to live decently in the village in this situation.

Other women of Nagreongo corroborated this basic story. According to the FCPB officers, the animatrice of Nagreongo was under an internal investigation, and she either had been transferred or left the organization and was now in southern Burkina Faso.

Five implementation solutions need to be highlighted. First, more resources must be expended on an aspect of the Credit Association accounting that even animatrices tend to find challenging: a general accounting ledger (Gizzi 2000). Record-keeping for the loans to members, their repayment installments, and savings deposits are numerous but quite straightforward and make up the majority of the pages in the Credit Association registry. The general ledger, however, is a record of all financial transactions and maintains a running balance of cash on hand and cash on deposit with the credit union. These ledgers must be updated at each meeting, balances be reconciled with cash on hand and the amount indicated in credit union passbook, and these balances must be reported to the members of the Credit Association. At the beginning and end of each meeting, the balances for members' savings and the group fund should be reported in a demonstrative manner to the entire membership. Perhaps a large poster-board can be used for this purpose, with "thermometer-style" graphics for women who are not literate. Animatrice and Credit Association officers need to obtain authorization from the entire membership for any spending from the group fund.

Second, more "spot audits" and supervisory visits are needed. In any large-scale financial institution there will inevitably arise occasional embezzlement. Clearly these occasional abuses need to be curtailed, and more importantly records must exist so that the embezzler, when caught (as Juliette was), can be convicted. Unannounced spot audits are essential for this type of decentralized credit delivery system. In the case above, Juliette stopped issuing receipts for payments and absconded with the account book, so it was difficult to prove that she had in fact obliged the women to repay more than they should have. 
Third, any visit to a village Credit Association makes it apparent that women in the Credit Association seem to know the program exclusively through the animatrice. For them, the animatrice is the program; sometimes programs are known by the name of the animatrice: "Juliette's program," "Lucie's money," or "Therèse's credit." Many women have never been to Ouagadougou or even to the regional capital. For them, the idea that they could go to an office and speak with the superiors of the animatrice cannot be imagined. Perhaps a type of ombudsman office could be set up for receiving visits by women who are members of the program, where program members could come in from the villages occasionally to receive training sessions or simply have occasions to share experiences. This would be a low-cost intervention that would enhance the self-supervising capabilities of the women in isolated rural Credit Associations.

Fourth, new lesson plans should be designed that specifically address the rights and responsibilities of women in the Credit Association: the right to demand a receipt for any payment; the right to have the account book explained or photocopied; the right to visit the central office and be heard; and the right to refuse a repayment pending an investigation by a superior. These lesson plans are not relevant just for the formal loans and group funds. All of the groups maintain separate, small, informal funds amassed through selfimposed fees for each cycle. The accounting for these funds was lacking, and in the case of Ipendo, the treasurer entrusted with safekeeping the funds had taken them with her on a trip to Côte d'Ivoire. No one knew when she was due to return.

Fifth, the Nagreongo episode made clear that other local authorities, such as local police, district officials, and magistrates, need to be continually apprised of rights and obligations incurred through program activities. Non-repayment of loans is probably not a crime punishable by imprisonment in the FCPB program, but embezzlement by an animatrice is.

\section{Conclusion}


Microfinance institutions expanding are rapidly through West Africa. These institutions are discovering something agricultural scientists learned a few decades ago. As the scientists tried to import "green revolution" techniques to West Africa, they quickly learned that highly variable climatic, topographic, and social conditions meant single-purpose improvements in crop varieties were unlikely to spread widely. The same is likely to be true for microfinance. While the FCPB has demonstrated that it is possible to achieve depth of outreach and at least moderate scale in rural West Africa, many challenges lie ahead.

The steps that need to be taken to meet the challenges involve both reform and experimentation. We have tried to highlight six design and implementation issues that senior managers should continue to explore vigorously, in consultation with staff on the ground. These six are as follows: 1) making mutual guarantee groups smaller, more central to non-repayment penalties; 2) offering more training in better business practices and more variety and experimentation in credit and savings mechanisms; 3) developing instruments to mitigate commodity price risk at the individual and program level; 4) becoming more consistent in the treatment of debts of deceased borrowers, and instituting a nominal insurance charge; 5) documenting, codifying and implementing new standard procedures to be followed in the event of non-repayment; and 6) preventing and mitigating the likelihood and effects of staff embezzlement.

In general, services offered must be flexible to better meet client needs and maintain retention while keeping costs low. Standardized loans, self-managed groups and highly decentralized delivery systems are very attractive in the start-up phase. As the finance institution matures and borrowers become more sophisticated, new mechanisms must be developed that respond to the differentiated borrowing and savings products that clients need to improve their livelihood security, smooth consumption and cope with shocks and life-cycle changes. It will continue to be a challenge to use self-management techniques, for example, in an environment of low literacy. A greater range of more targeted services, and emphasis on maintaining quality (supervision, training and an internal field-audit system), will involve either increases in interest rates and 
continued subsidies, or rapid improvements in productivity. Cost reduction and productivity-enhancing steps appropriate to the FCPB might include less-frequent Credit Association meetings, targeted lending products that allow loans to grow, differentiated interest rate structures and more formal involvement of animatrices in maintaining account books. The FCPB is in a good position to deepen the microfinance program for women because it already has considerable experience offering a variety of financial products to other target clients and because it has a large pool of liquidity in the form of member savings. Other credit institutions may not have as much experience or flexibility. 
Table 1: Major credit institutions in West Africa registered with the Microcredit Summit

\begin{tabular}{|c|c|c|}
\hline Institution & Country & Total Clients \\
\hline Kafo Jiginew & Mali & 82,898 \\
\hline United Indigenous Commercial and Petty Traders Association & Sierra Leone & 50,000 \\
\hline F.A.A.R.F. & Burkina Faso & 48,953 \\
\hline Alliance de Crédit et d'Épargne Pour la Production & Senegal & 48,781 \\
\hline Fédération des Caisses Populaires du Burkina (FCPB) & Burkina Faso & 48,247 \\
\hline PAMECAS & Senegal & 41,540 \\
\hline Calmeadow/Microstart-Benin & Benin & 35,000 \\
\hline Réseau des Caisses d'Épargne et Crédit & Senegal & 30,000 \\
\hline Nyèsigiso, Union des Caisses D'Épargne et de Crédit & Mali & 21,360 \\
\hline Nsoatreman Rural Bank Ltd & Ghana & 16,424 \\
\hline CBDIBA & Benin & 14,367 \\
\hline Freedom from Hunger Ghana & Ghana & 12,500 \\
\hline IRC,SEAD Project & Cote d'Ivoire & 12,000 \\
\hline Federation des ONG du Senegal & Senegal & 11,850 \\
\hline Réseau des caisses Rurales d'E. Crédit du Walo & Senegal & 11,807 \\
\hline International Christian Revival Ministry & Ghana & 10,870 \\
\hline Association pour la promotion et l'Appui au Devt. de Micro-Entreprises & Benin & 10,313 \\
\hline Sinapi Aba Trust & Ghana & 10,250 \\
\hline Pride/Finance & Guinea & 9,738 \\
\hline GIE Guinedou Service d'Appui aux CVECB Pays Dogon & Mali & 9,500 \\
\hline JEMENI & Mali & 8,819 \\
\hline Programme d'Appui aux Collectivités Décentralisées & Mali & 8,780 \\
\hline Projet Caisses Villageoises d'Epargne et de Crédit Autogerees & Mali & 8,316 \\
\hline PRIDE & Guinea & 8,270 \\
\hline Conseil National Pour la Promotion et le Developpement des Caisses Populaires & Senegal & 8,000 \\
\hline Groupement Togolais a'Épargne et de credit & Togo & 7,884 \\
\hline Centre d'Appui Nutritionnel et Economique aux Femmes & Mali & 7,506 \\
\hline VITA/PRIDE/UCOFIS & Guinea & 7,500 \\
\hline Wages & Togo & 7,439 \\
\hline FUCEC-Togo & Togo & 7,000 \\
\hline Femme Développement Enterprise en Afrique & Senegal & 6,949 \\
\hline Agora Consult & Burkina Faso & 6,600 \\
\hline CREDO Burkina Faso & Burkina Faso & 6,594 \\
\hline Catholic Relief Services Senegal & Senegal & 6,327 \\
\hline Reseau CMEC & Cote d'Ivoire & 6,151 \\
\hline Association for International Development and Services & Sierra Leone & 5,553 \\
\hline
\end{tabular}

Source: Microcredit Summit secretariat, 2001. 
Table 2: Statistics from selected credit programs in West Africa

\begin{tabular}{lcccc}
\hline Country & Niger & Benin & Mali & Burkina Faso \\
\hline Acronym of program & CPEC & FECECAM & CVECA & PPPCR \\
Year established & 1990 & 1977 & 1986 & 1988 \\
Number of clients & 5,000 & 166,000 & 21,495 & 10,000 \\
Ave. loan size outstanding (USD) & 151 & 408 & 136 & 59 \\
Ave. loan/GNP per capita & 0.66 & 1.1 & 0.54 & 0.20 \\
Ave. loan term (months) & 5 & 9 & 6 & 6 \\
Growth of loan portfolio & $478 \%$ & $50 \%$ & $64 \%$ & $177 \%$ \\
\hline
\end{tabular}

Source: [Fruman, 1998 \#51] 
Table 3: Expansion of FCPB Credit with Education program

\begin{tabular}{lrrrrrrrr}
\hline & \multicolumn{8}{c}{ End-of-year values of indicators } \\
\hline & 1993 & 1994 & 1995 & 1996 & 1997 & 1998 & 1999 & 2000 \\
Credit Associations & 38 & 158 & 263 & 470 & 876 & 1,219 & 1,428 & 1,494 \\
Members & 1,204 & 4,445 & 8,311 & 14,944 & 22,721 & 29,998 & 27,711 & 33,004 \\
Borrowers & 854 & 3,228 & 7,050 & 11,726 & 22,321 & 27,214 & 11,303 & 27,517 \\
Borrowers per CA & 22 & 20 & 24 & 22 & 25 & 22 & 8 & 18 \\
Outstanding Loans & 19,172 & 65,714 & 341,110 & 933,929 & $1,073,608$ & $1,469,932$ & 863,265 & $1,152,531$ \\
(USD) & & & & & & & & \\
Average loan (USD) & 22 & 20 & 48 & 79 & $48^{*}$ & 52 & 76 & 42 \\
\hline
\end{tabular}

* Major devaluation of the FCFA in '96 explains drop in loan size using dollar equivalent 


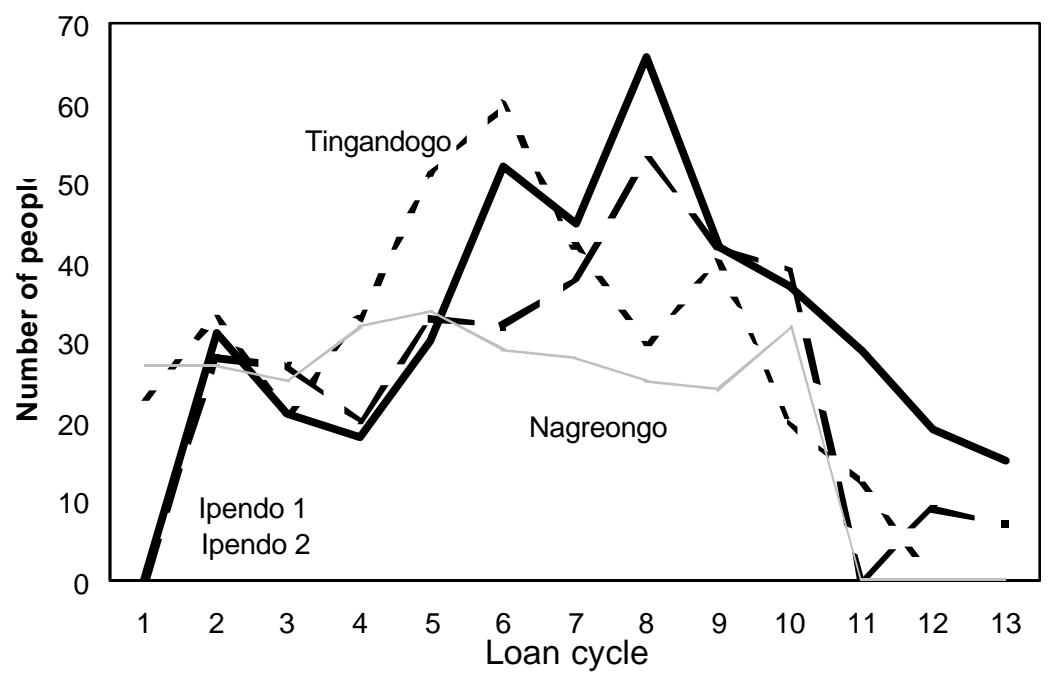

Chart 1: Number of people borrowing in each association by loan cycle, 1993-2000 


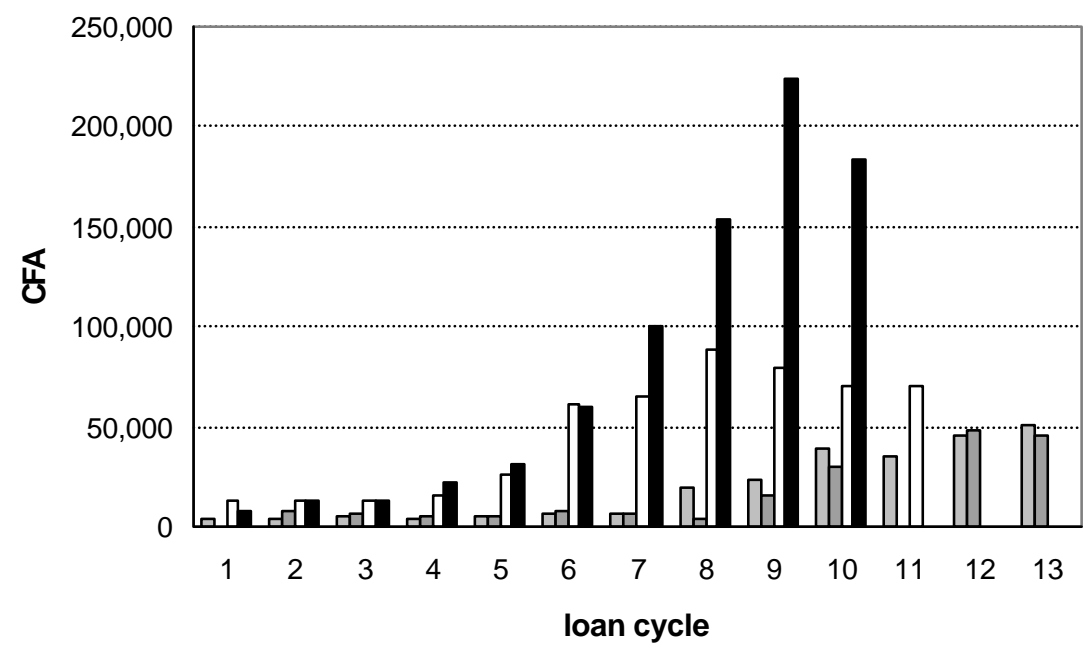

$\square$ Ipendo $1 \square$ Ipendo $2 \square$ Tingandogo $\square$ Nagreongo

Chart 2: Average loan size in each association by loan cycle, 1993-2000 
References

Brand, Monica. "More bang for the buck: Improving efficiency." The MicroBanking Bulletin, no. 4 (2000).

Chao-Beroff, Renee. "Developing Financial Services in Disadvantaged Regions: Self- managed Villages Savings and Loan Associations in the Dogon Region of Mali." In Microfinance for the Poor?, ed. Hartmut Schneider, 87-108. Paris: OECD, 1997.

Coleman, Brett, and Michel Cadalen. Community Banks for the Women of Tanghin-Dassouri Department. Burkina Faso: Catholic Relief Services, 1998.

Edgcomb, Elaine, and Laura Barton. Social Intermediation and Microfinance Programs: A Literature Review., 1998. Microenterprise Best Practices.

Frankel, Larry, Jeff Ashe, Gloria Almeyda, and Julie Kelley Detwiler. Bridging the Gap: Cooperative Development Organizations and Private Voluntary Organizations in Microfinance. Washington, D.C.: USAID and AMA Technologies Inc, 1999. Mimeo.

Fruman, Cecile. Mali: Self Managed Village Savings and Loan Banks (CVECA Pays Dogon). Washington, DC: The World Bank, 1998. Case Studies in Rural Finance.

Fruman, Cecile. Benin: FECECAM. Washington, DC: The World Bank, 1999. Case Studies in Rural Finance.

Fruman, Cécile, and Julia Paxton. "Outreach and sustainability of savings-first vs. credit-first financial institutions: A comparative analysis of eight microfinance institutions in Africa." (1998).

Ghatak, M., and T. W. Guinnane. "The economics of lending with joint liability: theory and practice." Journal of Development Economics 60, no. 1 (1999): 195-228.

Gizzi, Mark. Product Assessment of Credit with Education in Malawi. Davis, CA: Freedom from Hunger, 2000. Mimeo.

Kevane, Michael. Qualitative Impact Study of Credit with Education in Burkina Faso. Davis, CA: Freedom from Hunger, 1996. Research Paper No. 3.

Larivière, Sylvain, and Frederic Martin. Innovations in Rural Microfinance: The Challenge of Sustainability and Outreach. , 2000. Mimeo.

McDonald, Jennifer. "Credit Unions: Efficient and Profitable Financial Intermediaries." The MicroBanking Bulletin, no. 4 (2000).

MkNelly, Barbara, and Karen Lippold. Practitioner-Led Impact Assessment: A Test in Mali. : Assessing the Impact of Microenterprise Services (AIMS), 1998. Mimeo. 
Montgomery, R. "Disciplining or protecting the poor? Avoiding the social costs of peer pressure in micro-credit schemes." Journal of International Development 8, no. 2 (1996).

Nelson, Candace, Barbara MkNelly, Kathleen Stack, and Lawrence Yanovitch. Village Banking: The State of the Practice. Small Enterprise and Education Promotion (SEEP) and United Nations Development Fund for Women (UNIFEM). , 1996.

Oberdorf, Ed. Microfinance: Conversations with the Experts. : Calmeadow and ACCION International, 1999.

Ouattara, Korotoumou, Mayada Baydas, and Julia Paxton. Niger Credit Unions: Caisses Populaires d'Epargne et de Crédit. Washington, DC: The World Bank, 1998. Case Studies in Rural Finance.

Pal, Miriam. An Examination of the Grameen Bank Model and its Replication in Burkina Faso. , 1995. Environment and Social Policy Working Paper Series EST-13.

Paxton, Julia. "Determinants of Successful Group Loan Repayment: An Application to Burkina Faso." Ph.D., The Ohio State University, 1996.

Paxton, Julia, Douglas Graham, and Cameron Thraen. "Modeling Group Loan Repayment Behavior: New Insights from Burkina Faso." Economic Development and Cultural Change 48, no. 3 (2000): 639-55.

PLAN. PLAN's Experience with High Performance Microfinance in West Africa. : PLAN Burkina Faso, 1999. Mimeo.

Rutherford, Stuart. The Poor and Their Money An essay about Financial Services for Poor People. : Institute for Development Policy and Management, University of Manchester, 1999.

Schreiner, Mark. A Cost-Effectiveness Analysis of the Grameen Bank of Bangladesh. St. Louis: Washington University, 1999. Mimeo, Center for Social Development No. 99-5.

Stack, Kathleen, and Didier Thys. "A Business Model for Going Down Market: Combining Village Banking and Credit Unions." The MicroBanking Bulletin Focus: Reaching the Poor Issue, no. No. 5 (2000).

URCPSO. Proposition de Programme de Credit, Epargne Avec Education. Burkina Faso: L'Union Regionale de Caisses Populaires du Sud-Ouest, 1999.

Webster, Leila. "The Informal Sector and Micro-finance Institutions in West Africa [Implications for the World Bank]." CGAP Newsletter 1 (1995): 9-10.

Wright, Grahan. A critical review of savings services in Africa and elsewhere. : Microsave, 2000. Mimeo.

Wydick, B. "Can social cohesion be harnessed to repair market failures? Evidence from group lending in Guatemala." Economic Journal 109, no. 457 (1999): 463-475. 
*We wish to thank Chris Dunford, Beth Porter and Kathleen Stack for comments on earlier drafts of the paper, as well as the insights of two anonymous referees. Celestine Toe and Marguerite Acolo at the FCPB in Ouagadougou were very helpful. The views presented in this paper are those of the authors alone, and do not represent the official views of either Freedom from Hunger nor the FCPB. We are grateful to both organizations for asisstance in conducting the research.

\section{Endnotes}

\footnotetext{
${ }^{1}$ Although not much is published on these programs, many reports are available online. Among them are: (ChaoBeroff 1997; Coleman and Cadalen 1998; Fruman 1998; Fruman 1999; Kevane 1996; MkNelly and Lippold 1998; Ouattara, Baydas, and Paxton 1998; PLAN 1999; URCPSO 1999; Webster 1995).
}

${ }^{2}$ The program was developed through a three-year joint venture between FCPB and Freedom from Hunger, a U.S.based nonprofit. Freedom from Hunger developed Credit with Education and provided FCPB with technical and logistical support, and collaborative grant solicitation for start-up costs. FCPB provided loan capital from its member savings and recruited, hired and integrated new staff into its existing structure of branch credit unions. Other credit unions have also adopted Credit with Education in Mali (Kafo Jiginew and Nyèsigiso), Madagascar (OTIV), Togo (FUCEC), Benin (FECECAM) and the Philippines (CUES). A variety of NGOs in Africa and Latin America have also adopted this strategy. See www.freefromhunger.org for more details. 